\title{
Quando e como encontros e desencontros parecem implodidos...
}

\author{
José André Peres Angotti ${ }^{1}$. https://orcid.org/0000-0001-8211-4113 \\ Demétrio Delizoicov Neto ${ }^{2}$. https:/ / orcid.org/0000-0002-5970-3400
}

Escrevemos no trimestre final deste ano singular para o país e nossa gente, cuja maioria continua bastante sofrida e com futuro indefinido, e o coletivo Ensino de Ciências sofreu perdas de nossos amigos de profícuo convívio nas suas trajetórias e contribuições marcantes: Ernst Hamburger, Alberto Gaspar e Marta Pernambuco.

Em particular, dedicamos este editorial à Marta, que nos deixou em maio após enfermidade crítica acelerada que inviabilizou sua resistência em breve período. Tivemos o privilégio de sua companhia e amizade desde o final da graduação no Instituto de Física (IF) da Universidade de São Paulo (USP) e início do Mestrado pioneiro em Ensino de Ciências/Física - parceria Instituto de Física e Faculdade de Educação da USP -, em meados da década de 1970. Com Juarez Melgaço, que realizou pós-doutoramento sob a supervisão dela na Universidade Federal do Rio Grande do Norte (UFRN), publica artigo neste número de Ciência \& Educação, justamente sobre criatividade e silêncio, interculturalidade, formação de educadores indígenas e conhecimentos tradicional e científico, campo fértil de investigação recente que a amiga se aproximou desde as primeiras etapas de implantação. Com dupla origem assumida, era paulistana de nascimento, escolaridade e estudos, até o doutoramento na FEUSP; e potiguar por opção, exercendo exemplarmente sua profissão docente e de pesquisa na UFRN em Natal, há cerca de quatro décadas.

Marta vai se forjando como uma intelectual educadora, fruto de uma práxis altamente comprometida por parâmetros éticos compromissados, em particular, com a questão quem educar? Aspecto de fundamental importância para a constituição de uma nação que somente nos anos 1940, depois de quase meio século da proclamação da República e cinco séculos do início da colonização europeia, compromete-se a implementar uma educação pública como obrigação do Estado, ainda assim por apenas quatro anos. Após isso, demorou cerca de um quarto de século para ampliar a obrigatoriedade de uma educação pública com oito anos. Terminou o século XX sem que a nação se visse obrigada a oferecer escolaridade universal com duração de doze anos. Um atraso na formação cultural e na constituição da cidadania da maioria da população brasileira. Demorou quase uma década, após o início do século XXI, para que o

\footnotetext{
1 Universidade Federal de Santa Catarina (UFSC), Programa de Pós-Graduação em Educação Científica e Tecnológica, Florianópolis, SC, Brasil. E-mail: <angotti@ufsc.br>.

${ }^{2}$ UFSC, Centro de Ciências da Educação, Departamento de Metodologia de Ensino, Florianópolis, SC, Brasil.
} 
Estado brasileiro fosse obrigado a oferecer uma Educação Básica pública gratuita de doze anos. Dentre outras limitações decorrentes da mazela com a educação escolar pública, enfrentamos o déficit de dezenas de milhares de professores das ciências da natureza formados para atuar no ensino médio.

Sem perder o foco da Educação em Ciências, mas tendo, cada vez mais, clareza do seu papel como intelectual orgânica num país que ao longo da sua história esteve relativamente pouco preocupado para com a educação para além de uma elite, Marta vai aprofundando aspectos do problema originado com essa dívida, ao se distanciar e analisar o papel da escola e do currículo escolar ao longo de sua trajetória de vida.

Um marco a ser destacado é a sua tese de doutorado, defendida na Faculdade de Educação da USP em 1994, como deixa transparecer o título por ela escolhido: Educação e escola como movimento: do ensino de ciências à transformação da escola pública! Mais do que um título pretencioso, ela, de fato, faz reflexões teóricas considerando dados empíricos vivenciados com a sua participação em uma equipe de docentes e de pós-graduandos da USP que contribuíram, através de assessorias, com a iniciativa pioneira de construir, junto com a rede de ensino público do município de São Paulo, durante o período 1989-1992, uma educação progressista, fundamentada por uma perspectiva ético-transformadora, quando a Secretaria Municipal de Educação de São Paulo teve Paulo Freire como secretário. São várias as publicações, algumas, inclusive, de autoria da própria Marta, que têm como objeto a implementação dessa perspectiva educacional, tanto na rede de ensino do município de São Paulo, como em outras, pertencentes a municípios de vários Estados, como desdobramento do que fora produzido pela iniciativa pioneira na capital paulista.

Por sua vez, como pode ser observado em uma simples consulta ao Google, ou em qualquer "buscador", por meio de vários sites que homenageiam Marta - e também tendo como referência a sua produção acadêmica - ela amplia a atuação que teve como educadora comprometida com uma educação progressista, ao coordenar o Curso de Pedagogia da Terra e ao integrar uma equipe dedicada à formação permanente de docentes universitários que atuam nas Licenciaturas em Educação do Campo nas Áreas de Ciências da Natureza e Matemática, oferecidas por várias universidades federais.

Seu envolvimento com a perspectiva educacional de Paulo Freire na educação escolar fez com que fosse convidada para participar de um evento na Alemanha, que ocorrerá em Hamburgo de 9 a 11 de novembro de 2018 (PAULO..., 2018). Os organizadores solicitaram que ela fizesse uma conferência sobre os avanços da implementação da concepção Freireana na escola. Contudo, com a sua repentina ausência, a coordenação do evento informou que está providenciando outra alternativa.

Em articulação com as categorias diálogo e problematiz̧ação, cada vez mais pertinentes e relevantes para a nossa educação formal e não formal, cabe ainda lembrar e celebrar os 50 anos da Pedagogia do Oprimido neste ano, que suscitou outros diversos eventos de caráter local, nacional e internacional, dentre os quais registramos "Celebrando Paulo Freire: 50 anos da Pedagogia do Oprimido” (CONGRESSO..., 2018), sediado na Universidade do Porto, em Portugal, e a II Conferência Internacional Paulo Freire: O legado Global, promovido pela Universidade Federal de Minas Gerais, em Belo Horizonte (II CONGRESSO..., 2018). 


\section{Referências}

II CONGRESSO Internacional Paulo Freire: o legado global. Disponível em: < https:// muraldeeventos.com.br/eventos/ii-congresso-internacional-paulo-freire-o-legado-globalbelo-horizonte-mg-28-04-a-01-05-2018/>. Acesso em: 22 out. 2018.

CONGRESSO Internacional: 50 anos depois da pedagogia do oprimido. Disponível em:

$<$ https:/ / sigarra.up.pt/fpceup/pt/noticias_geral.ver_noticia?p_nr=38597>. Acesso em: 22 out. 2018.

PAULO Freire Kongress 2018. Disponível em: <https://www.freirehamburg2018.de/>. Acesso em: 22 out. 2018. 
